\title{
An Indian hospital study of viral causes of acute respiratory infection in children
}

\author{
A. JAIN, A. PANDE, P. K. MISRA*, A. MATHURt and U. C. CHATURVEDI \\ Postgraduate Departments of Microbiology and *Paediatrics, K. G. Medical College, Lucknow 226 003, India
}

\begin{abstract}
Summary. From Sept. 1986 to Jan. 1989, a hospital-based study was conducted on 736 children, under 5 years of age, with acute respiratory infection. Nasopharyngeal secretions were examined for viruses by culture and by immunofluorescence. Viruses were detected in $22 \%$ of specimens: respiratory syncytial $(5 \%)$, parainfluenza $(5 \%)$, influenza A $(4 \%)$, influenza B $(2 \%)$, adenovirus $(3 \%)$, measles $(3 \%)$. The highest rates of detection were with patients diagnosed clinically as pneumonia or upper respiratory tract infection. The case fatality rate was very high ( $43 \%)$ in children with measles virus infection.
\end{abstract}

\section{Introduction}

In developing countries, acute respiratory infection (ARI) is a major cause of illness and death in children, ${ }^{1}$ mainly in those below 1 year of age. ${ }^{2,3}$ It has been estimated that about $20 \%$ of infants born in developing countries fail to survive beyond their fifth birthday and $20-84 \%$ of childhood mortality is attributable to ARI as an underlying or a contributing cause. ${ }^{4,5}$

Bacterial pathogens play a great role as a primary or secondary cause of severe lower respiratory tract disease in developing countries, but respiratory viruses are prevalent and are probably the primary causal agents of most ARI. ${ }^{4}$ There are substantial differences in epidemiological patterns of ARI in children between the developed and developing world. ${ }^{5,6}$ Accurate data on the incidence of respiratory viruses in ARI is limited, hence more work is needed, particularly relating to microbiological and clinical description of ARI in developing countries. We have studied viral causes of ARI in young children by virus culture and by indirect immunofluorescence for rapid diagnosis.

\section{Materials and methods}

\section{Patients}

Children presenting with ARI attending Outdoor and Indoor Paediatric Clinics of Gandhi Memorial and Associated Hospitals, Lucknow, were investigated for respiratory virus infection. The children were selected for the study if they were $<5$ years old, ARI was of less than 1 week's duration and no antibiotic had been given previously.

Received 20 July 1990; revised version accepted 19 Jan. 1991.

† Correspondence should be sent to Professor A. Mathur.

\section{Specimen collection and transport}

From Sept. 1986 to Jan. 1989, 736 specimens of nasopharyngeal secretions were collected with a fine nasal catheter passed through one nostril to the nasopharynx. Secretions were aspirated by suction pump into a mucus extractor, and the tube was slowly withdrawn while suction continued, so that superficial epithelial cells were collected also; $2 \mathrm{ml}$ of Minimum Essential Medium, $\mathrm{pH} 7 \cdot 2$, containing gelatin $5 \mathrm{mg}$ / $\mathrm{L}$, penicillin $400 \mathrm{U} / \mathrm{L}$, streptomycin $400 \mu \mathrm{g} / \mathrm{L}$ and nystatin $200 \mu \mathrm{g} / \mathrm{L}$ were sucked into the mucus extractor. The specimens were taken on wet ice to the virus laboratory immediately after collection.

\section{Virus culture}

Secretions were centrifuged $(1500 \mathrm{~g}, 10 \mathrm{~min})$ at $4^{\circ} \mathrm{C}$. The supernate was cultured in chick-embryo allantoic and amniotic cavities for the isolation of influenza viruses, and in primary monkey kidney tissue culture for the isolation of parainfluenza and measles viruses and adenovirus. Viruses were identified by haemagglutination inhibition (for influenza viruses) and neutralisation tests as described previously. ${ }^{7}$

\section{Immunofluorescence (IF)}

The deposits of the centrifuged secretions were mixed well with cold saline to break the mucus; they were centrifuged $(10 \mathrm{~min}, 2500 \mathrm{rpm})$ at $4^{\circ} \mathrm{C}$ and washed three times with saline. The cells were collected and diluted to $c .8-10$ cells/high-power field; smears were prepared on multispot glass slides and fixed in chilled acetone for $10 \mathrm{~min}$. They were stored at $-70^{\circ} \mathrm{C}$ until tested. Smears were stained for influenza viruses $A$ and $B$, parainfluenza viruses 1 and 3, adenovirus, measles virus and respiratory syncytial virus (RSV), by indirect $\mathrm{IF}^{8}$ with Wellcome reagents. 


\section{Results}

Viruses were detected in $164(22 \%)$ of the 736 specimens (table I). Of these, 30 specimens gave positive results by culture only, 67 by IF only, and 67 by both methods.

The clinical diagnosis was upper respiratory tract infection (URTI) in $276(38 \%)$, croup in $84(11 \%)$, bronchiolitis in $89(12 \%)$ and pneumonia in $287(39 \%)$. Their association with various viruses and the case fatality rates are shown in table II.

Table III shows the age and sex distribution of cases: the highest incidence was in children under 1 year of age, and males predominated over females. Influenza A, RSV and adenovirus predominated in children under 2 years, whereas measles virus was detected most frequently in children over 1 year of age.

The figure shows the monthly detection rates for each virus. No consistent seasonal variation was found.

\section{Discussion}

Viruses were detected in $22 \%$ of our clinical cases of ARI in children under 5 years of age, a similar rate to those found by other workers. ${ }^{9,10}$ The rates were similar in males $(23 \%)$ and females $(21 \%)$, although there were twice as many males as females in our study (table III). Our experience at Lucknow is that, whatever the clinical disease, female children are usually not brought to the hospital until their condition is very serious, and this delay reduced the proportion of females in our study.

Mortality due to virus infection was low except in cases of pneumonia due to measles. Most of these deaths were in children aged 1-4 years, presumably because maternal immunity protected infants in their first year. Occasional deaths were noted with other viruses. All had pneumonia complicated with bacterial infections, and malnutrition was commonly associated with measles (unpublished data); this probably contributed to the severity and very high case fatality rate.

Table I. Virus detection in nasopharyngeal specimens from 736 cases of ARI

\begin{tabular}{|c|c|c|c|c|}
\hline \multirow{2}{*}{ Virus detected } & \multicolumn{4}{|c|}{ Number $(\%)$ of specimens positive by } \\
\hline & culture & IF & $\begin{array}{l}\text { both culture } \\
\text { and IF }\end{array}$ & $\begin{array}{c}\text { either culture } \\
\text { or IF }\end{array}$ \\
\hline Influenza A & 22 & 25 & 17 & $30 \quad(4)$ \\
\hline Influenza B & 8 & 10 & 6 & 12 (2) \\
\hline Parainfluenza 3 & 19 & 16 & 14 & $21 \quad(3)$ \\
\hline Parainfluenza 1 & 15 & 14 & 12 & 17 (2) \\
\hline RSV* & $\ldots$ & 37 & $\ldots$ & $37(5)$ \\
\hline Adenovirus & 23 & 12 & 11 & 24 (3) \\
\hline Measles & 10 & 20 & 7 & $23(3)$ \\
\hline Total & 97 & 134 & 67 & $164(22)$ \\
\hline
\end{tabular}

*RSV detectable by IF only.

Table II. Association between clinical diagnosis and virus detected

\begin{tabular}{|c|c|c|c|c|c|c|c|c|c|}
\hline \multirow{3}{*}{$\begin{array}{l}\text { Clinical } \\
\text { diagnosis }\end{array}$} & \multicolumn{9}{|c|}{ Number of cases/number $(\%)$ of deaths for } \\
\hline & \multirow{2}{*}{$\begin{array}{l}\text { all } \\
\text { clinical } \\
\text { cases }\end{array}$} & \multirow{2}{*}{$\begin{array}{l}\text { all } \\
\text { virus-positive } \\
\text { cases }\end{array}$} & \multicolumn{7}{|c|}{ cases in which the virus detected was } \\
\hline & & & infl. A & infl. B & parainfl. 3 & parainfl. 1 & RSV & adeno & measles \\
\hline URTI & $\begin{array}{c}276 / 0 \\
(0)\end{array}$ & $46 / 0$ & $18 / 0$ & $3 / 0$ & $9 / 0$ & $3 / 0$ & $3 / 0$ & $9 / 0$ & $1 / 0$ \\
\hline Croup & $\begin{array}{l}84 / 11 \\
(13)\end{array}$ & $26 / 0$ & $5 / 0$ & $2 / 0$ & $4 / 0$ & $7 / 0$ & $5 / 0$ & $3 / 0$ & 0 \\
\hline Bronchiolitis & $\begin{array}{c}89 / 5 \\
(6)\end{array}$ & $26 / 1$ & $1 / 0$ & $1 / 0$ & $1 / 1$ & $3 / 0$ & $20 / 0$ & 0 & 0 \\
\hline Pneumonia & $\begin{array}{c}287 / 37 \\
(13)\end{array}$ & $66 / 16$ & $6 / 0$ & $6 / 1$ & $7 / 1$ & $4 / 2$ & $9 / 1$ & $12 / 1$ & $22 / 10$ \\
\hline Total & $\begin{array}{c}736 / 53 \\
(7)\end{array}$ & $\begin{array}{c}164 / 17 \\
(10)\end{array}$ & $\begin{array}{l}30 / 0 \\
(0)\end{array}$ & $\begin{array}{c}12 / 1 \\
(8)\end{array}$ & $\begin{array}{l}21 / 2 \\
(10)\end{array}$ & $\begin{array}{l}17 / 2 \\
(12)\end{array}$ & $\begin{array}{c}37 / 1 \\
(3)\end{array}$ & $\begin{array}{c}24 / 1 \\
(4)\end{array}$ & $\begin{array}{c}23 / 10 \\
(43)\end{array}$ \\
\hline
\end{tabular}

URTI, upper respiratory tract infection; infl., influenza; parainfl., parainfluenza. 


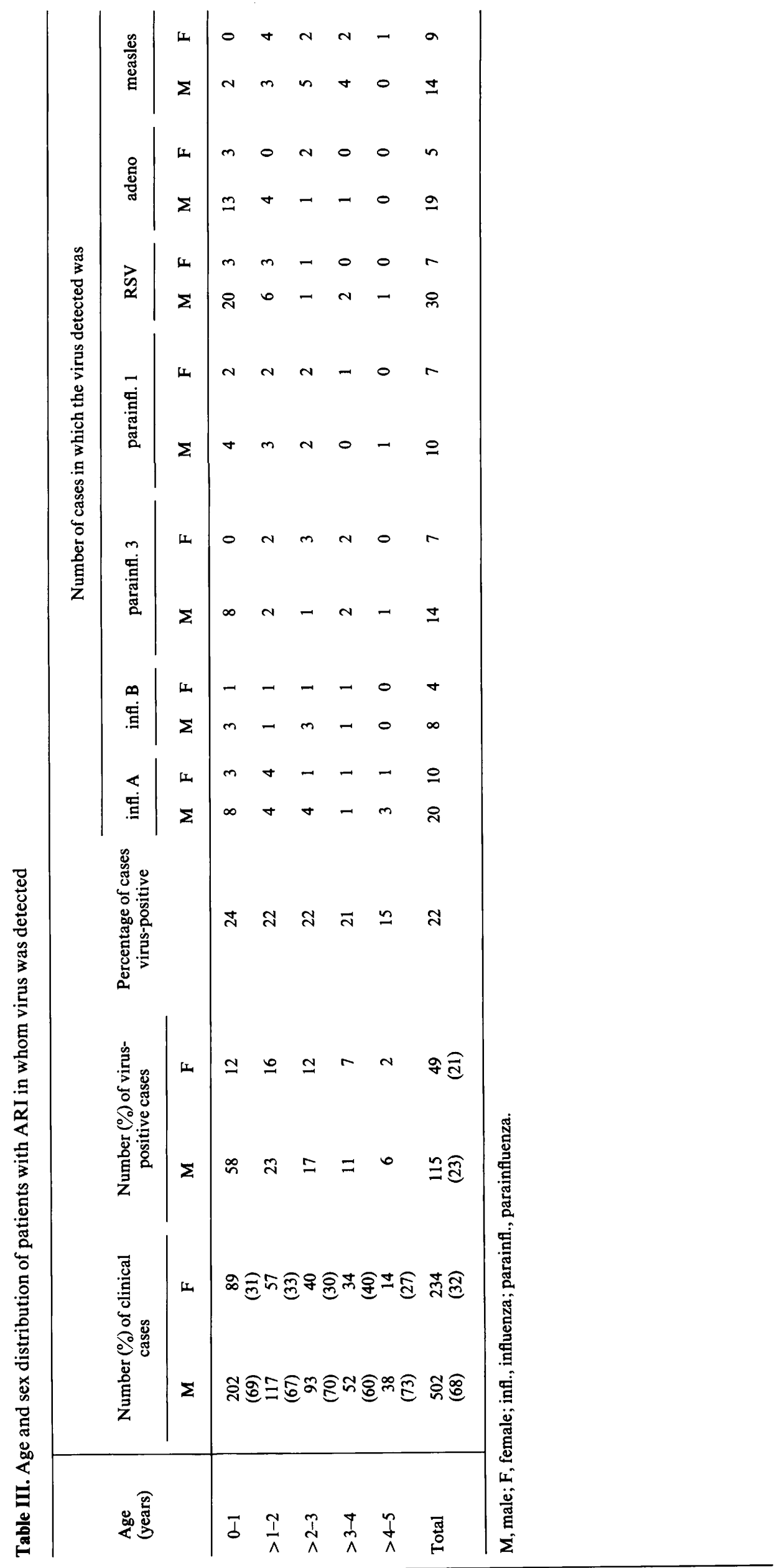




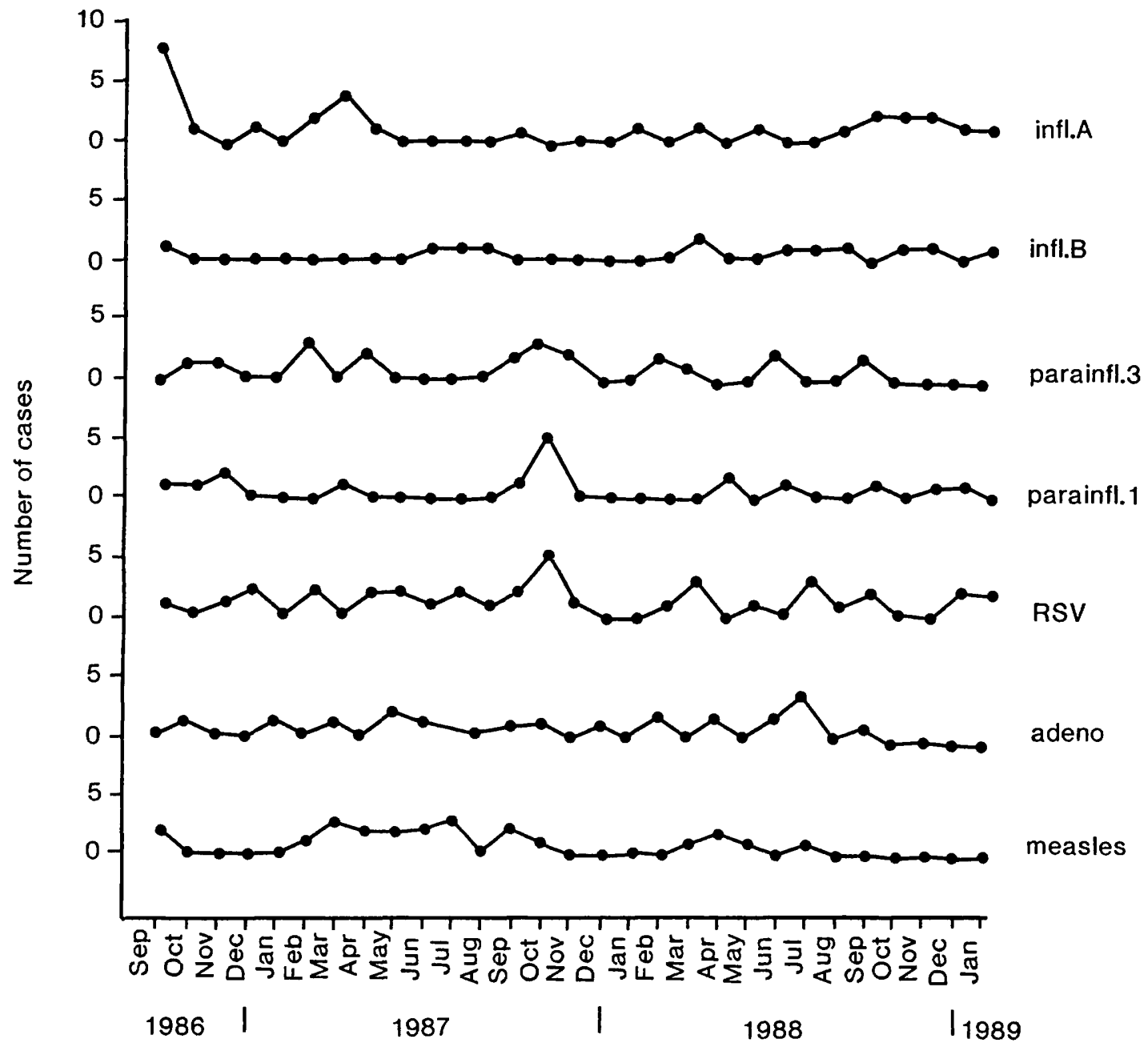

Figure. Seasonal variation in detection of respiratory viruses in children with ARI. (infl., influenza; parainfl., parainfluenza).

RSV was detected in $23(8 \%)$ of 291 cases in children under 1 year (table III), commonly presenting as bronchiolitis (table II). Even higher rates (9-20\%) have been reported previously. ${ }^{9,11}$ RSV was present throughout the year, whereas others ${ }^{3}$ have reported outbreaks in Europe during the winter each year or in alternate years, and outbreaks in the rainy season have occurred in tropical Trinidad ${ }^{12}$ and Panama. ${ }^{13}$

Influenza $A$ and $B$ viruses together accounted for 42 cases (table II), half of them presenting as URTI. There was only slight seasonal variation. A study from Kuala Lumpur ${ }^{10}$ described findings similar to ours, and another from Pune, India, ${ }^{14}$ mentioned an outbreak in June 1986, while we experienced this in September 1986. Maybe this was because in Pune, June is the month of heavy rains, whereas in Lucknow it is September.

Parainfluenza viruses 1 and 3 were detected in 38 $(5 \%)$ of our cases. Some studies ${ }^{3,9,10}$ have recorded rates as low as $2 \%$, another ${ }^{15}$ as high as $35 \%$; and even one from Lucknow ${ }^{7}$ reported $14 \%$. We have found that parainfluenza viruses may be associated with any type of clinical presentation, whereas others ${ }^{16}$ reported them mainly in cases of croup. Four of our patients died, all with malnutrition and Staphylococcus aureus infection associated with lobar pneumonia (unpublished data). We found no obvious seasonal variation; but a previous study from Lucknow ${ }^{7}$ showed a peak in the winter, and Downham et al. ${ }^{16}$ described a peak in the summer; Glezen and Denny ${ }^{2}$ described biennial epidemics caused alternatively by types 1 and 2 viruses.

Adenovirus was responsible for $3 \%$ of cases, mainly in children under 1 year of age presenting with pneumonia. No seasonal variation was recorded. Many workers have described similar findings, ${ }^{7,9,10,15}$ though Mathur et al. ${ }^{7}$ did not find adenovirus in cases of pneumonia.

The present study has attributed a substantial amount of respiratory illness to virus infection. IF can be used as an important tool for the rapid identification of viral pathogens responsible for ARI in children.

The authors thank Professor D. L. Miller for his valuable suggestions in the presentation of this work, and the International Development Research Centre, Canada, for financial support. 


\section{References}

1. Chanock RM, Parrott RH. Acute respiratory disease in infant and childhood: present understanding and prospects of prevention. Pediatrics $1965 ; 36: 21-39$.

2. Glezen WP, Denny FW. Epidemiology of acute lower respiratory disease in children. $N$ Engl J Med 1973; 288: 498-505.

3. Ørstavik I, Grandien M, Halonen P et al. Viral diagnoses using the rapid immunofluorescence technique and epidemiological implications of acute respiratory infections among children in different European countries. Bull WHO 1984; 62: 307-313.

4. Steinhoff MC. Acute respiratory infections in children (A new priority for community health workers). Indian J Community Med 1986; 11 : 1-9.

5. Narain JP. Epidemiology of acute respiratory infections. Indian $J$ Pediatr 1987; 54: 153-160.

6. A programme for controlling acute respiratory infections in children : memorandum from a WHO meeting. Bull WHO $1984 ; 62: 47-58$.

7. Mathur A, Singh UK, Tandon HO, Chaturvedi UC. Pattern of some viruses in acute respiratory illness during 1972-73 at Lucknow. Indian J Med Res 1979; 69: 546-552.

8. Gardner PS, McQuillin J. Immunofluorescent techniques, control of specificity and non-specific fluorescence. In Rapid virus diagnosis : application of immunofluorescence, 2nd edn. London, Butterworths. 1980: 56-91.
9. Berman S, Duenas A, Bedoya A et al. Acute lower respiratory tract illness in Cali, Columbia: a two-year ambulatory study. Pediatr 1983; 71 : 210-218.

10. Ong SB, Lam KL, Lam SK. Viral agents of acute respiratory infections in young children in Kuala Lumpur. Bull WHO $1982 ; 60$ : 137-140.

11. Soběslavský O, Sebikari SRK, Harland PSEG, Skrtić N, Fayinka OA, Soneji AD. The viral etiology of acute respiratory infections in children in Uganda. Bull WHO $1977 ; 55: 625-631$.

12. Spence L, Barratt N. Respiratory syncytial virus associated with acute respiratory infections in Trinidadian patients. Am J Epidemiol 1968; 88: 257-266.

13. Maletzky AJ, Cooney MK, Luce R, Kenny GE, Grayston JT Epidemiology of viral and mycoplasmal agents associated with childhood lower respiratory illness in a civilian population. J Pediatr 1971; 78: 407-414.

14. Rao BL, Thite NY. Virological and serological study on the new influenza variant A (H1N1) strain; A/Singapore/6/86 in Pune, India, 1986. Indian J Med Res 1987; 86: 813-815.

15. Denny FW, Clyde AW. Acute lower respiratory tract infections in nonhospitalized children. J Pediatr 1986; 108: 635-646.

16. Downham MAPS, McQuillin J, Gardner PS. Diagnosis and clinical significance of parainfluenza virus infections in children. Arch Dis Child 1974; 49: 8-15. 